\title{
THE DANELAW RECONSIDERED: COLONIZATION AND CONFLICT IN VIKING-AGE ENGLAND
}

\author{
Ben Raffield
}

\section{Introduction}

During the late ninth and early tenth centuries, England bore witness to a period of social and political turmoil, as large tracts of the landscape were settled and occupied by Scandinavian colonists. This process was initiated in 865 , when a large viking fleet described in the Anglo-Saxon Chronicle as a 'Great Army' arrived on the shores of East Anglia. The Great Army spent the next thirteen years traversing the length and breadth of England, during which time it subdued and later occupied large portions of the kingdoms of Northumbria, East Anglia, and Mercia. Subsequent waves of colonists are likely to have followed, leading to a substantial influx of immigrants over the next few decades. While the scale of the settlements has been debated (Loyn 1962; Cameron 1965; Sawyer 2001; Hadley 2006; Leslie and others 2015), Jane Kershaw and Ellen Røyrvik (2016, $1678-79)$ have recently argued that, by the end of the tenth century, some 20,000-35,000 settlers had established themselves in the regions of Yorkshire,

\section{Ben Raffield (ben.raffield@arkeologi.uu.se) is a researcher at Uppsala University}

\begin{abstract}
The purpose of this study is to address long-standing interpretative frameworks for the discussion of the 'Danelaw', a term that has been applied since the medieval period to a large area of eastern and northern England that was occupied by viking raiding groups and other immigrant settlers during the ninth and tenth centuries AD. The article highlights several potential issues concerning widely held perceptions of the Danelaw and its main subsidiary element - the 'Five Boroughs' - as geopolitical and cultural entities. On the basis of a lack of historical and archaeological evidence for coordinated territorial defence and cooperation between the groups occupying the landscape, the study calls the concepts of the Danelaw and Five Boroughs into question. I argue that a shift in scholarly focus to more local and regional processes of consolidation and social development would provide fresh insights into political and military organization in Viking-Age England, while also shedding light on processes of violence, colonization, and creolization as these played out across the settled landscape.
\end{abstract}

Keywords: Viking Age, Danelaw, conflict, migration, colonization, political organization, defence, creolization, cultural interaction

Viking and Medieval Scandinavia 16 (2020), 181-220 BREPOLS PUBLISHERS DOI 10.1484/J.VMS.5.121523

This is an open access article made available under a CC BY-NC 4.0 International License. 
Lincolnshire, Norfolk, and Suffolk alone. The total number of Scandinavian settlers is therefore likely to have been significantly higher.

The area of the settlements, now generally perceived as comprising modernday East Anglia, the southern and eastern midlands, Yorkshire, and parts of Cumbria, Lancashire, and Cheshire, is often described as the 'Danelaw', a term that has been applied since the medieval period as a means of distinguishing the areas of England that fell under Scandinavian control in the period following the 870 s. Its ease of use means that it has long provided a convenient framework upon which scholars have developed their knowledge, both within the context of the Scandinavian settlements and the longer-term development of the English realm. As recent scholarship shows, this is a term that remains very much in use today (see e.g. Baker and Brookes 2013; Blinkhorn 2013; Jesch 2015; Kershaw 2017). Continued references to the 'Danelaw', however, are curious and as I shall argue here problematic, especially in light of various archaeological discoveries that have been made in recent decades. When taken at face value, its application to the ninth- and tenth-century landscape reinforces a perception of permanence, of an easily defined and dominant Scandinavian cultural milieu within England, and of political unity across a wide geographical area. Despite this, it is becoming increasingly clear that the political and cultural landscape of the 'Danelaw' was far more complex and dynamic than has previously been believed, and that our treatment and use of this term requires re-evaluation. This article will examine the historical and archaeological evidence for colonization and conflict within the area of the Scandinavian settlements in order to study the political and social make-up of the Danelaw and its most well-known subsidiary element - the 'Five Boroughs'. The study argues that a shift in focus towards more local and regional studies of the Scandinavian occupation would offer more to our understanding of Viking-Age England than current research frameworks allow.

Before continuing, it is worth clarifying the terminology used in this article. Throughout the discussion I will refer largely to the settlement of 'Scandinavians', using the word 'viking' in a more militaristic context to describe the primarily Scandinavian piratical raiding fleets and large, migratory 'armies' that were operating in western Europe during the mid-late ninth century. While the use of the word 'Scandinavian' to refer to settler groups is admittedly problematic given increasing evidence for the multi-ethnic composition of both the colonists and viking fleets operating in Europe at this time (see McLeod 2014; Raffield 2016; Raffield and others 2016), the term is used here simply as a means of distinguishing new arrivals - and their descendants - from the regional populations of England. 
The rest of the article is structured as follows. In the following section I provide a brief outline of the historical context for the Scandinavian settlements of the late ninth century, as well as the subsequent West Saxon and Mercian conquest of the Scandinavian occupied territories in the tenth century. I then explore the conceptual origins of the terms 'Danelaw' and 'Five Boroughs' in order to discuss their relevance and applicability within modern scholarship. The discussion will then turn to the archaeological record in order to consider whether this can provide insights into the nature of the Scandinavian occupation in eastern and northern England. The study concludes with a discussion of the evidence and some suggestions for future research.

\section{Conflict in Ninth-and Tenth-Century England}

Any archaeological or historical study of ninth- and tenth-century England must acknowledge the formative impacts of conflict and colonization in shaping the political, social, and cultural landscape. Although the historical timeline of the period is well known, it is worth providing a brief overview of the Scandinavian settlements and their eventual incorporation into the English realm.

As noted above, the events relating directly to the Scandinavian settlement and occupation of eastern and northern England began in 865 with the arrival of the 'Great Army' in East Anglia. Once posited as a small and relatively insignificant force numbering at most a few hundred combatants, it is now accepted that the Great Army was a large and demographically diverse group, with a constituent population numbering at least in the low thousands. It is apparent that the army was not merely seeking loot and plunder but also land to settle, with archaeological evidence indicating the presence of families, artisans, and merchants alongside combatants (see McLeod 2006, 2013, 2014; Blackburn 2011; Williams 2013, 2015; Raffield 2016). Crucially, the Great Army did not represent any particular state or political entity. It was a composite force, with its 'military' structures resting on cooperation between numerous autonomous raiding groups that were bound to each other in temporary alliances of mutual benefit. This caused the overall size of the army to fluctuate rapidly, as new groups joined or broke off from the main force in pursuit of individual goals.

The arrival of the Great Army marked the beginning of thirteen years of near constant warfare. Northumbria was quickly subjugated following the capture of York in 866, East Anglia was conquered in 869 and Mercia in 873 (Anglo-Saxon Chronicles in Swanton 2000, 68-72). From the 870s, elements of the Great Army began to settle the English landscape. In 874, a large contingent of the 
army under the command of a leader named Halfdan left the main force in order to campaign and later settle lands in Northumbria, and in 876 further groups established themselves in Mercia. ${ }^{1}$ The remnants of the Great Army, now under the command of Guthrum, attempted to conquer Wessex but were defeated by King Alfred at the Battle of Edington in 878. The surviving elements of the army retreated to Cirencester, and in 879 to East Anglia where they settled under Guthrum's rule (Anglo-Saxon Chronicles in Swanton 2000, 72-76).

Following the turbulent events of the 870 s, a short period of consolidation took place. Alfred retained control of Wessex and for a short while appears to have ruled alongside an enigmatic Mercian king named Ceowulf, who may have originally been installed as a puppet ruler in western Mercia by the Great Army. Ceowulf disappears from the historical record after 877 , and by the early 880 s western Mercia seems to have fallen under the hegemonic influence of Wessex, being ruled first by the lord Æthelred and subsequently his wife - Alfred's daughter, Æthelflæd, following his death in 911. With the exception of aiding a viking attack on Wessex in 885 , Guthrum reigned relatively peacefully in East Anglia until his death in 890 , and at some point prior to this the boundaries between his and Alfred's kingdom were formally ratified in a treaty (commonly referred to as the 'Alfred-Guthrum treaty', discussed below).

From the 890s, conflict once again began to intensify in England. Wessex was repeatedly harassed by large viking fleets, and it is at this time that Scandinavian raiding armies from East Anglia, Northumbria, and eastern Mercia began to conduct large-scale raids into Wessex and western Mercia. These armies, like the Great Army of the 860s-70s, were often composite forces comprising groups from numerous settlements and regions. While they sometimes met with success, more often than not they were defeated by West Saxon and Mercian field armies, and by the end of the century the balance of military power was clearly shifting in favour of their adversaries. Alfred had gained control of London, the Thames Valley, and likely southern Essex by the time of his death in 899 . He was succeeded by his son Edward the Elder who continued to make inroads into the Scandinavianheld territories. The catastrophic defeat in battle of a Scandinavian force at Tettenhall, in 910, paved the way for the conquest of several major strongholds in the South Midlands. Another major Scandinavian defeat at Tempsford resulted in the capitulation of East Anglia in 917, which according to the Anglo-Saxon

${ }^{1}$ Given the lack of detail provided by the Chronicle, it is difficult to establish the extent of these settlements. While it is often assumed that both eastern and portions of western Mercia were settled at this time, the eastern settlements may have taken place at a later date; Gareth Williams pers. comm. 
Chronicle was swiftly followed by the general surrender of Scandinavian elites in eastern Mercia (Anglo-Saxon Chronicles in Swanton 2000, 94, 102-04). Edward annexed the western portion of Mercia following the death of Æthelflæd in 918, and in doing so became the ruler of a consolidated West Saxon state. His successor Æthelstan would come to rule all of England after gaining control of Northumbria in 927. Although the north would remain contested by the Hiberno-Norse rulers of Dublin (the Ui Ímair) for some time, the region was finally brought under English control following the death of Erik Bloodaxe in 954.

\section{The Danelaw, the Five Boroughs, and the Alfred-Guthrum Treaty}

The economies, social organization, and culture of the 'Danelaw' have long been studied by scholars concerned with daily life, politics, and society in Viking-Age England. The decades either side of the new millennium witnessed a particularly intensive surge of interest in the subject, leading to numerous publications and conferences devoted to its study (e.g. Hart 1992; Hadley 2000; Hadley and Richards 2000; Graham-Campbell, Hall, Jesch, and Parsons 2001; Higham and Hill 2001). While the seminal works produced at this time set the tone of scholarship that continues to be accepted today, scholars have since explored and built upon the questions raised during earlier studies. Some have focused on the nature of the groups conducting the settlements, while others have sought to better understand how the Scandinavian settlements shaped the sociopolitical, economic, and cultural landscapes (Blackburn 2011; McLeod 2014; Harrison 2015; Haldenby and Richards 2016; Kershaw and Røyrvik 2016; Raffield 2016; Kershaw 2017). A number of attempts have also been made to critically re-examine and deconstruct the concept of the 'Danelaw' itself. In many cases, these works have highlighted the evidently complex nature of the Scandinavian settlements. David Dumville (1992), Paul Kershaw (2000), Matthew Innes (2000), and Katherine Holman (2001), for example, have all drawn attention to the ephemerality of the Danelaw's supposed territorial boundaries in both historical and legal sources. Gareth Williams (2013) has similarly stressed the urban focus of the Scandinavian settlements, and in doing so questioned the applicability of a territorial model for the Danelaw to the settled landscape of the ninth and tenth centuries. Other scholars such as Lesley Abrams (2001a), Dawn Hadley (2001, 2002), and more recently Shane McLeod (2014) have noted a lack of archaeological evidence for a dominant Scandinavian cultural presence within eastern and northern England following the initial settlements, drawing attention instead to the rapid acculturation of Scandinavian colonists to English customs 
and beliefs. In light of this critique, it seems strange that the term 'Danelaw' has retained its currency within academic research.

It is widely acknowledged that concept of the 'Danelaw' as a political and geographical territory does not have its origins in the ninth or tenth century. Rather, it emerges within eleventh-century law codes as a means of highlighting and accounting for variations in legal custom as they manifested across different parts of the English realm. The conceptual origins of the Danelaw can likely be traced back to the 970s, when King Edgar decreed that the rights of the lay population mid Denum ('among the Danes') should be maintained as best as their legal frameworks allowed, while the laws mid Englum ('among the English') remained under the direct control of the king (see IV Edgar; Laws in Robertson 1925, 32-33). The phrase on Dena lage or '[areas] under Danish law' first appears in the so-called Laws of Edward and Guthrum, compiled by Archbishop Wulfstan II of York in around 1008, and almost simultaneously in the law code VI Ethelred (see Laws in Attenborough 1922, 106-07; Laws in Robertson 1925, 102-03; Innes 2000, 76-77; Hadley 2002, 50). Like IV Edgar, VI Æthelred juxtaposes references to on Dena lage with the phrase on Angla lage, or '[areas] under English law' (Laws in Robertson 1925, 102-03), but neither code specifically defines these respective areas geographically. The term 'Danelaw' was adopted more systematically in the laws of Canute in 1020, which is argued by Matthew Innes to reflect an attempt to establish a sense of legal unity in England at a time when the kingdom was facing a re-emergent viking threat (II Canute; Laws in Robertson 1925, 180-81; Innes 2000, 76).

There is evidently much that could be made of this discussion, and a review of these terms that combines legal, linguistic, and historical perspectives is long overdue, but for the purposes of this article it is worth noting that the concept of the Danelaw does not seem to have emerged as a well-defined geographical entity until the twelfth century (Innes 2000, 76-77). In the legal treatise Leges Henrici Primi, the kingdom of England is described as constituting three parts - Wessex, Mercia, and the Danelaw, each of which were governed by their own laws (Leges Henrici Primi in Downer 1972, 97). Later medieval and antiquarian scholars would add individual shires to these territories in order to create a more tightly defined geographical definition of the Danelaw (Abrams 2001b, 130-31). Thus, by the twelfth century, a term that was initially used to describe distinctions between cultural and legal practices in different parts of England had come to be used to describe a territorial unit, and it is this definition of the Danelaw that generally prevails today (Abrams 2001b, 128-30).

Unlike the 'Danelaw', the notion of the Five Boroughs has its origins in the historical record, but its application to the sociopolitical reality of the 
Scandinavian settlements is equally problematic. Early models for the political landscape of the Danelaw were promoted by nineteenth- and early twentiethcentury scholars whose heavily materialist interpretations of artefactual evidence led them to identify the so-called kingdoms of York and East Anglia as the major political powers in the region. They also sought to present the Five Boroughs of eastern Mercia as an important Scandinavian enclave (see e.g. Worsaae 1852; Kendrick 1930; Shetelig 1940). The word 'borough' derives from OE burh (pl. byrg), a term that is used to denote a defended settlement that served both militaristic and non-militaristic functions (Baker and Brookes 2013, 38-39; Historic England 2019). The first historical reference to the Five Boroughs occurs in 942, when The Anglo-Saxon Chronicle (MS A) records that: 'Eadmund cyning, Engla peoden, maga mundbora, Myrce geeode, dyre dædfruma, swa Dor scadep, Hwitanwylles geat 7 Humbra ea, brada brimstream. Burga fife, Ligoraceaster 7 Lin[d]cylene 7 Snotingaham, swylce Stanford, eac Deoraby' (Anglo-Saxon Chronicle in Bately 1986, 73) (King Edmund, lord of the English, guardian of kinsmen, beloved instigator of deeds, conquered Mercia, bounded by The Dore, Whitwell Gap and Humber river, broad ocean-stream; five boroughs: Leicester and Lincoln, and Nottingham, likewise Stamford also and Derby) (Anglo-Saxon Chronicles in Swanton 2000, 110). In light of this explicit reference, early scholars often portrayed the Five Boroughs as a semi-autonomous satellite territory appended to either of the larger 'kingdoms' of York and East Anglia. Haakon Shetelig (1940, 84), for example, argued that eastern Mercia was allocated to five chieftains 'as a confederation of five earls - each residing in his town - called the Five Boroughs'. Sir Thomas Downing Kendrick (1930, 236-41) similarly described these settlements as a coalition of defensive military centres that were established following the Great Army's settlements of 877 . He also asserted that four 'southern boroughs' were established at Northampton, Bedford, Cambridge, and Huntingdon. Jens Jacob Asmussen Worsaae (1852, 31-32), however, had earlier ascribed the Five Boroughs with a more independent status, arguing that they were a 'little separate state' in their own right.

Aside from this brief reference in the Anglo-Saxon Chronicle, historical sources provide no further insights into the nature of the Five Boroughs during the ninth and tenth centuries. Certainly there is no evidence to suggest that these byrg formed a cohesive political or military confederation within the area of the Scandinavian settlements (Hall 1989). Indeed, it is notable that they appear within the Anglo-Saxon Chronicle as part of an alliterative poem, in which Lincoln is specifically paired with Leicester, Nottingham (Snotingaham) with Stamford, and Derby with 'the Danes' (Williams 2015, 26-30). The only other known historical references to these settlements occur at the turn of the eleventh 
century, first in a law code issued by King Æethelred at Wantage (III Æthelred), and later in the Anglo-Saxon Chronicle entries for the years 1013 and 1015, the latter of which also makes a reference to Seofonburgum or 'seven boroughs' (Laws in Robertson 1925, 64-65; Anglo-Saxon Chronicles in Swanton 2000, 143, 146; Anglo-Saxon Chronicle in Irvine 2004, 71).

Given the lack of detailed evidence concerning the status of the Five Boroughs, it is striking that they continue to be portrayed - at least implicitly - as some sort of political enclave or bloc today (Williams 2011a, 2013; Raffield 2013). Certainly it cannot be denied that these were prominent administrative centres; their important status within the early medieval landscape is demonstrated by the fact that, with the exception of Stamford, they all lend their names to historic counties. Later references in III Ethelred and the Anglo-Saxon Chronicle also imply that the idea of a confederation of byrg in eastern Mercia had gained at least some kind of legal and political significance by the eleventh century. It is important to recognize, however, that this is an explicitly English perspective and not necessarily one that was held by the Scandinavian settlers of the ninth and tenth centuries. If the Five Boroughs ever really did represent a political or administrative entity, then one likely context for its conception lies in the years immediately following their capture by King Edmund in 942. The consolidation of these town-fortresses as mutually supportive, strategic hardpoints would have significantly bolstered West Saxon defensive capabilities in the eastern Midlands, and may have been undertaken with a view to mitigating the potential for future aggression from York (Hall 1989, 205). The reality of the situation, however, is difficult to gauge given the limitations of the available sources. When viewed in wider perspective it is worth noting that the Five Boroughs represent just a few of many strategically located settlements that were constructed or occupied by Scandinavian settlers during the late ninth and early tenth centuries. If we look to the South Midlands, then it is also telling that Kendrick's (1930) so-called 'southern boroughs' of Cambridge, Northampton, Bedford, and Huntingdon, were not only major strongholds that possessed active raiding armies, but that they also retained their importance as political and administrative centres for historic counties. We should perhaps resist the temptation, therefore, to ascribe the Five Boroughs with a special kind of prominence.

What, then, can the historical record tell us about the political structure of the Scandinavian occupied landscape? If we expand our view to consider wider developments taking place within the landscape, then it is possible to glean some interesting insights into Scandinavian sociopolitical and military organization within the area of the settlements. Of particular note are the turbulent years of 914-18, a period when both Wessex and Mercia were making significant inroads 
into the South Midlands, eastern Mercia, and East Anglia. It is worth quoting several entries from the Anglo-Saxon Chronicle at length:

\section{Manuscript A, 918 [914]}

ða for Eadweard cyning to Buccinga 'hamme' [...] 7 Purcytel eorl hine gesohte him to hlaforde 7 pa holdas ealle, 7 pa ieldstan men ealle mæste ðe to Bedanforda hierdon 7 eac monige para pe to Hamtune hierdon. (Anglo-Saxon Chronicle in Bately 1986, 66)

(King Edward went to Buckingham [...] and Jarl Thurcytel sought him out as lord, and all the holds, and almost all the principal men who belonged to Bedford, and also many of those who belonged to Northampton.) (Anglo-Saxon Chronicles in Swanton 2000, 100)

\section{$919[915]$}

Her on pys gere Eadweard cyng for mid fierde to Bedanforda foran to Martines mæssan 7 beget pa burg, 7 him cirdon to mæst ealle pa burgware pe hie ær budon. (Anglo-Saxon Chronicle in Bately 1986, 66)

(Here in this year, before Martinmas, King Edward went with his army to Bedford and took possession of the stronghold, and almost all of the garrison who had earlier dwelt there turned to him.) (Anglo-Saxon Chronicles in Swanton 2000, 100)

$921[917]$

Pa æfter pam pa gi' e't pæs ilcan hærfestes gegadorode micel here 'hine' of Eastenglum ægper ge pæs landheres ge para wicinga pe hie him to fultume aspanen hæfdon [...] 7 foron to Mældune 7 ymbsæton pa burg [...] Pa paes forhrape pæs ilcan hærfestes for Eadweard cyning mid Westsexna fierde to Passanhamme $[. .]$. him cirde to Purferp eorl 7 pa holdas, 7 eal se here pe to Hamtune hierde [...] Pa giet æfter pam pæs ilcan geres foran to Martines mæssan for Eadwear 'd' cyning mid Westsexna fierde to Colneceastre [...] 7 se here pe to Grantanbrycge hierde hine geces synderlice him to hlaforde 7 to mundboran. (Anglo-Saxon Chronicle in Bately 1986, 67-68)

(Then yet again after that, the same harvest-time, a great raiding-army ${ }^{2}$ gathered together from East Anglia, both from the raiding-army in occupation and from those vikings whom they had enticed to help them [...] and went to Maldon, and

2 The term 'here' is ultimately ambiguous, being used to refer to armed groups of varying size and composition. While Swanton translates this term as 'raiding-army', many other translations are applicable. Garmonsway (1972), for example, prefers the more general term 'host'. 
besieged the stronghold [...] Then very quickly after this the same harvest-time, King Edward went with a West Saxon army to Passenham [...] And Jarl Thurferth and the holds turned to him, together with all the raiding-army which belonged to Northampton [...] Then still after that, before Martinmas the same year, King Edward went with a West Saxon army to Colchester [...] and the raiding-army that belonged to Cambridge individually chose him as their lord and protector.) (Anglo-Saxon Chronicles in Swanton 2000, 102-03)

\section{Manuscript C, 918}

Her heo begeat on hire geweald mid Godes fultume on foreweardne gear gesybsumlice pa burh æt Ligraceastre, 7 se mæsta dæl pæs herges pe ðærto hirde wearð underpeoded. (Anglo-Saxon Chronicle in O'Brien O'Keeffe 2001, 76)

(Here in the early part of this year, with God's help, she [Æthelflæd] peaceably got in her control the stronghold at Leicester, and the most part of the raidingarmies that belonged to it were subjected.) (Anglo-Saxon Chronicles in Swanton 2000, 103)

When taken together, these entries offer a potential window into the structure of the political landscape of the southern and eastern Midlands during the early tenth century. Although it is important to recognize that the authors of the Chronicle might have sought to over-exaggerate the Scandinavian tendency for capitulation, what becomes immediately apparent is that the actions of Scandinavian elites were not governed by any sense of wider ethnic or political affiliation, but rather by selfinterest and preservation. The so-called raiding armies inhabiting various regional territories similarly seem to have operated autonomously, with coordinated military action depending on the formation and maintenance of short-term alliances. In 910, for example, a large army from Northumbria, operating with other forces under the command of several kings, jarls, holds, and minor noblemen, is recorded as conducting raiding into Mercia (Chronicle of Ethelweard in Campbell 1962, 51-53). As noted above, the year 917 also saw a number of operations by composite raiding armies. The East Anglians seem to have been particularly active at this time, forming coalitions with armies from Huntingdon, Mercia, and a number of unnamed warbands in order to launch multiple offensives into English territory (Anglo-Saxon Chronicles in Swanton 2000, 103).

The Scandinavian model of military organization, which seems to have rested on the formation of short-term alliances between various elites and raiding groups, is deeply reminiscent of those prevailing among the large viking forces that were operating in western Europe during the ninth century (see Price 2014, 2016; Raffield 2016). These arrangements would have arguably provided raiding armies with a measure of flexibility by facilitating their ability 
to launch rapid, repeated raids into Wessex and Mercia. They were not, however, suited to territorial defence. As the entries in the Chronicle show, there were few coordinated attempts to counter West Saxon and Mercian advances into eastern England during the early tenth century. Indeed, the Chronicle implies a distinct lack of cooperation between regional elites - not only among the jarls who governed major strongholds, but also among less prominent members of the aristocracy (the 'holds') and the leaders of various raiding armies who inhabited the landscapes surrounding nodal byrg. As can be seen in the entries from the Anglo-Saxon Chronicle above, all of these groups seem to have actively participated in diplomatic negotiations. While the raiding armies of Northampton and Leicester, for example, had operated together on at least two occasions in 913 and 917, these settlements capitulated to Edward and Æthelflæd independently in two separate events, separated by around six months, in 917 and 918. The independence of Scandinavian elites is further emphasized when we note that, of the 'Five Boroughs' whose conquest or annexation is recorded in the Anglo-Saxon Chronicle (Derby [917], Leicester [918], Nottingham [918], Stamford [922]), none of these settlements are described as acting cooperatively in offensive operations prior to their surrender, and none are known to have sought or received military aid from the others. This certainly does not speak to the existence of a political or military confederation in eastern Mercia. Rather, it seems apparent that the 'Danelaw' was a politically fractured landscape inhabited by groups that looked first to secure their own interests before giving thought to cooperative action. This lack of cohesion effectively allowed Wessex and Mercia to make sweeping territorial gains moving into the tenth century.

The ephemerality of the Scandinavian political landscape is further revealed when we turn to the so-called Alfred-Guthrum treaty. The date of the treaty is uncertain, but it may have been agreed in the wake of the Battle of Edington, or perhaps following King Alfred's historically recorded occupation of London in 886 (see Whitelock 1979, 417; Haslam 2010, 2011). The treaty is most famously known for delineating the boundary between Alfred's and Guthrum's kingdoms, which is described as travelling 'up on Temese, 7 ðonne up on Ligan, 7 andlang Ligan oð hire æwylm, ðonne on gerihte to Bedanforda, ðonne up on Usan oð Wætlingastræt' (up the Thames, and then up the Lea, and along the Lea to its source, then in a straight line to Bedford, then up the Ouse to Watling Street: Laws in Attenborough 1922, 98, 99). The treaty also included legislation relating to trade, the payment of wergild, and the return of escaped slaves. While the wording of the treaty implies an effort to ensure peaceful and long-lasting cooperation between Wessex and East Anglia, the boundary outlined by the treaty was not a border in the modern sense of the term but rather a permeable 
frontier zone that did not prevent contact or conflict between those inhabiting the landscape on either side (see Laws in Attenborough 1922, 98; Whitelock 1979, 417-18; Lambert 2018, 22).

It is unlikely that the Alfred-Guthrum boundary remained in use for very long. Indeed, it has been suggested that the boundary quickly reverted to an older frontier on the River Ouzel, which lies some $14.5 \mathrm{~km}$ west of that stipulated in the treaty (Dumville 1992, 10; Haslam 2011, 127). This idea finds support in the Anglo-Saxon Chronicle, which records Edward the Elder as concluding a peace treaty with the East Anglians and Northumbrians at Tiddingford in 906 (AngloSaxon Chronicles in Swanton 2000, 94). Further evidence to support this assertion can be taken from S. 396, a grant by King Athelstan in 926 of Chalgrave, which indicates that land in the Toddington area of Bedfordshire $(c .5 \mathrm{~km}$ to the west of the Alfred-Guthrum boundary) was purchased from the Scandinavians and settled by English elites prior to 911 (Whitelock 1979, 581-83; Edgeworth 2007; Electronic Sawyer 2019). This latter example of diplomatic contact is especially interesting as it provides evidence of continuing but historically unattested political negotiations in the frontier region. As Matt Edgeworth $(2007,91)$ notes, the purchasing of land and the settling of elites in frontier zones may have represented a wider tactical approach to territorial annexation on the part of Edward the Elder, especially as the power of the East Anglian kings waned moving into the 910s. In exploiting the Scandinavians' willingness to sell land and negotiate their own diplomatic agreements, both the West Saxons and Mercians may have been able to make significant strategic gains without resorting to open warfare.

When taken together, the evidence examined thus far suggests that some of the key concepts regularly applied during discussions of Viking-Age England - in this case the 'Danelaw' and the 'Five Boroughs', are of questionable value to the study of the Scandinavian settlements of the ninth and tenth centuries. There is little historical evidence to support the idea of an autonomous or semiautonomous polity or political bloc in eastern Mercia, and the rapid erosion of the Scandinavian territories during the early tenth century implies a lack of political centralization and power on the part of elites, even in the areas that were nominally under the control of the East Anglian kings.

\section{The Scandinavian Occupation: A Review of Archaeological Evidence}

Having examined the concepts of the Danelaw, the Five Boroughs, and their application to the political landscape of the ninth and tenth centuries, I will now explore whether archaeological evidence can provide insights into the nature of political and military consolidation as it varied across eastern England. The 
discussion here is intended to expand upon that provided by Richard Hall in his seminal 1989 article, 'The Five Boroughs', published in Anglo-Saxon England.

\section{Urban Occupation and Defence}

During the late ninth and early tenth centuries, the construction and maintenance of fortified strongholds represented a primary means of establishing dominance over the landscape. While archaeological evidence for these activities should not be taken as an implicit proxy for political or military power, studying the ways in which Scandinavian colonists augmented and managed settlement defences can provide insights into the ability and desire of groups to establish, maintain, and garrison strategic locales within their sphere of influence. As fortifications represent a highly visible symbol of elite influence and permanence, the study of these sites can also shed light on the ways in which the landscape of power was mediated and contested.

Although only a few defended 'urban' settlements are known from Viking-Age Scandinavia - the most famous being Birka, Sweden, and the later fortification at Hedeby, Jutland - viking armies and raiding fleets (including the Great Army) are recorded as establishing fortified overwintering camps and raiding bases while operating in Europe during the mid-late ninth century. Excavations at a number of sites in the British Isles, such as Repton and Aldwark, England, and Woodstown and Linn Duachaill, Ireland, have now shown these locales to have been home to diverse populations engaging not only in warfare and raiding but also subsistence activities, craft production, and trade (see e.g. Biddle and Kjølbye-Biddle 1992, 2001; Clinton 2014; Russell and Hurley 2014; Hadley and Richards 2016; Raffield 2016, 2019). While some of the major longphuirt or 'ship bases' (sing. longphort) in Ireland developed into permanent towns, there is little evidence to suggest that the overwintering sites established by the Great Army in England remained occupied following the initial Scandinavian settlements of the 870s. The Scandinavian occupation instead seems to have focused on the seizure and development of urban sites as centres of political and military power, production, and trade (Williams 2013). Many of these sites were probably selected due to the existence of extant Roman or middle Saxon defensive circuits, or for their strategic siting on overland and riverine communication routes (see Hill 1981, 10). It is also apparent that some Scandinavian byrg such as those occupied by influential political leaders at Stamford, Huntingdon, and Bedford, were constructed anew. The brief period of Scandinavian political control, a lack of chronological definition, and the limitations imposed on archaeologists 
working in urban environments, however, mean that few settlements have yielded clear evidence for a Scandinavian presence during the ninth and tenth centuries.

Perhaps the strongest evidence for fortification construction and augmentation can be found at York - the first major stronghold to be captured by the Great Army in 866. Here, excavations have shown that the Roman and later Anglian defences were augmented in $c .900$, when earth was piled over them to form a bank into which was inserted a breastwork. To the south-west of the legionary fortress, in front of the walls, a palisade trench containing a piece of St Neots Ware may indicate a desire to strengthen areas where the Roman defences no longer provided adequate protection (Webster and Cherry 1972, 165; 1973, 151).

In Mercia and East Anglia, the picture of urban defence is difficult to interpret given the historically recorded programme of fortification construction that was undertaken by Edward the Elder and Æthelflæd following their capture of major Scandinavian strongholds during the early tenth century. In eastern Mercia, it is possible that similar modifications to the fortifications at York were made at Lincoln. Excavations have suggested that the Roman rampart in the lower city may have been raised through the dumping of rubbish and soil, with pottery dating this activity to the ninth-tenth centuries. A series of pits cut into this material and connected by a shallow U-shaped gully have been tentatively identified as a palisade. While the fills of these features contained late tenthcentury pottery, a lack of data prevents a more confident interpretation (Jarvis 1996, 8-9). The Roman fort at Little Chester, Derby, has also revealed possible evidence of modification. Excavations in the early 1970s encountered a rubble platform, sealing St Neots, Stamford, and Thetford ware, which had been abutted to the outside of the south-eastern defences, possibly in an effort to reinforce them (Sparey-Green 2002, 141-43). A fortification is hypothesized to have existed at Nottingham since the time of Offa (Haslam 1987), and excavations at Drury Hill and Woolpack street in 1969-70 encountered a large U-shaped ditch and associated rampart. At Drury Hill, the ditch cut a sunken-floored building dated c. 650-850 and was recut into a V-shaped profile at some point during the tenth century. This recutting was also noted at Woolpack Street. Given the lack of closely datable evidence, numerous contexts for the construction present themselves (Knight and Lomax 2015). The possible defences identified at Stamford, Lincolnshire, are more enigmatic still. Excavations in the area of St George's street identified a series of postholes and slots, associated with a possible turf bank, which was interpreted as a palisade by way of comparison with the late Saxon defences at Tamworth (Mahany, Burchard, and Simpson 1982, 10). While a lack of Roman and middle Saxon evidence increases the likelihood of the features dating from the Scandinavian occupation, the features were found 
to overlay both ninth- and tenth-century deposits, thereby similarly allowing for a construction date in the years following the Edwardian conquest of 918 (Mahany 1978, 11; Anglo-Saxon Chronicles in Swanton 2000, 103). The limited extent of the excavations and sparse nature of available dating evidence means that the features cannot be interpreted with confidence; indeed, it is uncertain whether the purported palisade is actually a defensive construction at all (Hall 1989, 197).

A number of urban sites in the South Midlands have also yielded some evidence for settlement defences. Perhaps the most convincing case for a potential Scandinavian fortification comes from Bedford, where excavations along Midland Road in the late 1990s encountered the southern edge of what seems to have been a large east-west running ditch. The ditch was confirmed as running for at least $70 \mathrm{~m}$ and was estimated to measure $c .3 .5-4 \mathrm{~m}$ in width. Only the upper fills were excavated, but these yielded a key of similar type to known ninth-century Anglo-Saxon examples, and quantities of mixed ninth-/ thirteenth-century pottery (hand-made Maxey ware or proto-St Neots ware, and both early and developed St Neots ware). The mixed composition of the finds is difficult to interpret, but they may represent waste material that had accumulated on an adjacent bank that was later backfilled into the ditch. The fills were sealed by a medieval road surface (Edgeworth 2004, 191). While further excavations are required to understand this feature, it may represent the northern boundary of the Scandinavian stronghold located on the north bank of the Great Ouse, noted as being occupied by a jarl named Thurcytel in 914 (Anglo-Saxon Chronicles in Swanton 2000, 100). At Northampton, the first town defences have been found to have consisted of a bank and palisade trench dating from the late Saxon period (Chapman 1998, 33, 36). The presence of Northampton and St Neots wares allows for a construction date both prior to and following the annexation of the region by Edward the Elder in 917, but the latter scenario would be supported by Paul Blinkhorn's (2013) updated chronology for the Northampton and St Neots wares. If this is the case, then we must consider that the Scandinavian defences either lie elsewhere or, importantly, that they never existed at all. While Northampton was home to an active raiding force during the early tenth century (see Anglo-Saxon Chronicles in Swanton 2000, 101), fortified settlements were not a ubiquitous feature of the landscape at this time. If Northampton was undefended, a lack of defensive infrastructure may have contributed to the settlement's rapid capitulation to Edward the Elder on two occasions, in 914 and 917. For the remaining historically attested Scandinavian centres in Mercia and the southern Midlands (including Leicester, Huntingdon, and Cambridge), the presence of late Saxon defences has yet to be confirmed archaeologically, though Leicester may have possessed a surviving circuit of Roman defences. There is 
no firm evidence to suggest a consistent policy of defensive construction and consolidation, but rather a variable approach that might reflect the limited power held by the elites that occupied individual urban sites.

In East Anglia there is tentative evidence for the instigation of defensive constructions at several major settlements during the ninth or tenth century. It is again difficult, however, to attribute this activity to the Scandinavian presence (Wade 1993, 148). At Thetford, Norfolk, it has been argued that the first defences to the south of the River Little Ouse were constructed during the late ninth or early tenth century, perhaps during the recorded occupation of the settlement by the Great Army in 869-70 (Anglo-Saxon Chronicles in Swanton 2000, 70). While excavations to the north of the river have identified an undated defensive ditch (Crowson 1999), those in the southern part of the town have located several substantial features that may represent various phases of defensive construction. In 1977, excavations at St Barnabas's hospital encountered two parallel late Saxon ditches measuring $7.7 \mathrm{~m}$ in width and $1.95 \mathrm{~m}$ in depth, and $c .3-3.4 \mathrm{~m}$ in width and $c .1 .35-1.70 \mathrm{~m}$ in depth respectively. Traces of a bank were identified inside the larger (northern) ditch. The ditches contained no datable finds, but they were sealed by late tenth-/early eleventh-century activity (Rogerson and Dallas 1984, 55). To the south of this site, more recent excavations at Jubilee Close located a substantial U-shaped ditch measuring $c .8 \mathrm{~m}$ in width and $2.95 \mathrm{~m}$ in depth, the secondary fill of which was dated by optically stimulated luminescence dating to $918 \pm 110$ years. This has been taken to indicate that Thetford obtained its first defences following East Anglia's capitulation to Edward the Elder in 917, or perhaps during the period of renewed viking raiding activity in the later tenth century, but the ditch may similarly represent just one of several phases of defensive activity during the late Saxon period (Boyle 2009, 14). Of course, the date range presented here does not rule out the possibility that the ditch at Jubilee Close was constructed at some point prior to 917 , and the temptation to ascribe material evidence to specific historical events may be misleading in this case.

Ipswich has also been argued to have gained its first defensive circuit during the period of Scandinavian control (Wade 1993, 148). Excavations at School Street, on the north side of the River Orwell, have shown the eastern defences to comprise a ditch and bank, the latter of which overlay a ninth-century metalled street. The ditch, which been filled by the end of the tenth century, was estimated to measure $c .2 .6 \mathrm{~m}$ wide and a maximum of $c .1 .7 \mathrm{~m}$ in depth. Its associated bank was at least $4.4 \mathrm{~m}$ wide but survived only to a height of $0.7 \mathrm{~m}$. Both features were buried under later town banks (Youngs, Clark, and Barry 1984, 241; Wade 2014). A V-shaped ditch, similarly proposed to represent the late Saxon defences, was identified during excavations at Shire Hall Yard a short distance to the 
south. The ditch, which was partially cut by the later medieval town defences, was estimated to measure $c .5 \mathrm{~m}$ in width and $c .2 \mathrm{~m}$ in depth (West 1963, 236, 291-95). The western defences were tentatively identified during excavations at the Magistrate's Court. The first phases comprised a large ditch $(c .7 \mathrm{~m}$ wide by $2 \mathrm{~m}$ deep) with possible evidence for an internal palisade and what appeared to be irregularly spaced stake or postholes inserted into its external lip. No associated bank could be identified. Although the feature was sealed by two later phases of Saxo-Norman activity it could not be closely dated. Allusions were drawn, however, to the defences of Tamworth prior to its refortification by Æthelflæd in 913 (Dunmore, Loader, and Wade 1976, 135).

At Norwich, evidence for substantial defences enclosing a proposed area of eighth- and ninth-century occupation and mercantile activity has been identified on the north bank of the River Wensum (Ayers 2011,77-78). Limited excavations at Botolph Street in 1975 identified a substantial V-shaped ditch, with pottery from the lower fills suggesting that it was open during the tenth century. The ditch had been recut twice. The first recut, on the eastern (inner) edge of the ditch, showed the feature to measure $c .6 \mathrm{~m}$ in width and at least $2 \mathrm{~m}$ in depth. The second recut, on the western edge of the two previous ditches was thought to broaden the ditch to measure $c .9 \mathrm{~m}$ in width. While the first recut was radiocarbon dated to $890 \pm 60$, dates obtained from the layer sealing this were confusingly early $(690 \pm$ 90). A layer sealing the primary fill of the second recut also provided an early date of $780 \pm 70$. It is possible that material may have infiltrated the ditch from the outside, in the first case perhaps from an associated bank (Davison and Evans 1985, 116). The same ditch was identified during test pit excavations in 2007. While the initial fills yielded no finds, subsequent fills contained eleventh- and twelfthcentury pottery. Further excavations in 2010 identified what was interpreted as the second recut of the ditch originally encountered in 1975, but these provided no additional dating evidence that might shed light on the chronological sequence of the defences (Percival and Westall 2008; Wallis 2010).

Given the ability of the Scandinavians in East Anglia to muster large raiding armies throughout the late ninth and early tenth centuries, as in 896, 903, and on multiple occasions in 893 and 917, it is possible that the East Anglian kings were also able to mobilize large labour forces for construction projects (see Anglo-Saxon Chronicles in Swanton 2000, 90, 92, 86-87, 101-02). The generally similar morphology of the defences noted above, as well as their broadly contemporaneous date, may indicate that elites were able to defensively consolidate their position in reaction to the rapidly changing political situation in southern England from the late ninth century. Without further secure dating evidence, however, it remains difficult to draw any firm conclusions at this time. 
Further insights into processes of political consolidation might also be gained from tentative evidence for the subversion of urban landscapes. As with fortification construction, the disruption of an established urban fabric can act as a powerful expression of elite influence and power. In Northampton a large stone hall, interpreted variously as a palace or minster structure (Williams 1984; Foard 1995; cf. Blair 1996), has been shown by archaeological excavations to have fallen out of use or have been demolished during the late ninth century or early tenth century. Robbed-out trenches of the walls were filled with late Saxon pottery, mainly Northampton ware, and radiocarbon dates taken from the fills of a silted-up gully immediately to the south of the hall provided dates of 870 \pm 85 and $940 \pm 85$. It is at this time that the site was turned over to industrial activities (Williams 1984, 131; Foard 1995, 111). The Scandinavian settlements provide an attractive context for these developments, and it cannot be ruled out that the abandonment or demolition of the stone hall was a deliberate act intended to send out a clear signal that the area was under new management. A similar situation might be observed at Stamford, where excavations at the Norman castle encountered two concentric, pre-conquest ditches separated by a berm, which seem to have enclosed the high ground to the north of the River Welland (Mahany 1978; forthcoming). ${ }^{3}$ Evidence for a possible palisade trench and rampart was identified inside the inner ditch, and it has been suggested that these may have enclosed a Mercian royal residence. A lack of evidence for in-situ decomposition or palisade collapse, as well as the homogeneity of the material that filled the palisade trench and part of the inner ditch, was taken to indicate that the palisade had been deliberately dismantled. A coin of Alfred and sherds of redpainted Stamford ware found in one of the ditches may indicate that this activity took place in the decades surrounding the turn of the tenth century (Mahany forthcoming). The Stamford ware seems to have been the product of a kiln found immediately outside the outer ditch, which yielded an archaeomagnetic date of $850 \pm 50$ (Mahany and Roffe 1983; Hall 1989). If the site was indeed a Mercian royal residence, then perhaps its destruction can similarly be seen as an act of subversion and consolidation within the context of the Scandinavian settlements (though for an alternative interpretation see Haslam 2017).

In sum, reliable archaeological evidence for processes of political and military consolidation within the area and period of the Scandinavian settlement remains elusive. It is uncertain whether defended settlements were occupied or developed as part of a wider system of strategic defence, through a succession of piecemeal

${ }^{3}$ Draft report in the possession of David Roffe. It is planned to bring the report to publication in the next few years and deposit the papers in The Collection, Lincoln. 
developments, or in some cases whether efforts were made to establish defensive constructions at all. Certainly there does not seem to be any evidence for a 'grand strategy' of settlement and occupation. Instead, variation in the development of the settlements seems to have reflected the disparate approaches of the colonists themselves. While it is possible that large-scale defensive constructions were instigated in East Anglia during the ninth or early tenth centuries, there is no evidence for a coherent programme of public works in the Midlands. Indeed, some historically attested Scandinavian strongholds have yielded little or no evidence for defensive consolidation at all. It is important to recognize, however, that the sites discussed here represent just a few of the many potential fortifications that might have been constructed or occupied by Scandinavian settlers. While numerous settlements have been posited as locations of both Scandinavian and English byrg, a lack of datable evidence makes it difficult to untangle the individual threads of data that might speak to patterns of urban settlement and defence across the landscape (Raffield 2013, 173-85).

If we look to changes taking place within urban settlements themselves, then one potentially interesting aspect of the Scandinavian occupation relates to the subversion of elite sites and architecture. Tentative evidence for what seems to be a deliberate destruction or abandonment of elite structures at Stamford and Northampton may speak to a desire for intrusive regional elites to assert their identity and authority in the wake of the settlements. We of course should not expect incoming settlers to have universally asserted a disruptive presence within the settlements under their control, but in some cases this might have been perceived as a politically expedient means of establishing power.

\section{Production, Trade, and Identity}

The situation of major Scandinavian strongholds on overland and riverine communication routes not only had strategic implications, but also economic and social ones. The occupation and establishment of defended settlements would have created favourable environments within which craft specialization and commerce could flourish, and it is now apparent that a number of sites were important centres for production and both regional and long-distance trade.

Archaeological studies of major urban settlements and their hinterlands have now provided good evidence to show how craft production and trade facilitated the emergence and development of local, regional, and more cosmopolitan cultural identities in the years following the Scandinavian settlements. In East Anglia, a number of disc brooches of Anglo-Saxon manufacture but incorporating 
Scandinavian artistic styles have been analysed by Jane Kershaw (2013). The spatial clustering of these brooches indicates that they were produced by urban craftworkers located primarily at Norwich, and that urban populations were the main consumers of this material. The recovery of similar objects in the wider rural landscape, however, also suggests that these goods were traded regionally, and it is even possible that local manufacturing centres existed outside of major urban settlements (Kershaw 2013, 138, 140-43; Ten Harkel 2013a, 178-82). Evidence for the emergence of new material styles and fashions can also be seen at Lincoln. During the middle Saxon period, the crumbling ruins of the Roman colonia had been occupied only by a small, non-urban population. From the late ninth century, however, Lincoln experienced a surge of occupational and industrial activity, which by the tenth century had transformed it into one of the most important settlements in the region. Archaeological excavations at Flaxengate have identified evidence for the mass production of dress accessories during this period. The objects produced there, including hooked tags and brooches made of base-metals and alloys, possess designs that draw on a mix of Scandinavian, AngloSaxon, and European influences (Perring 1981; Ten Harkel 2013a, 177-85). The excavations also uncovered a tenth-century Continental polychrome-enamelled brooch of a type similar to others found in Anglo-Scandinavian contexts across northern and eastern England, as well as moulds used for creating Continentalstyle strap-ends (Ten Harkel, Weetch, and Sainsbury 2016).

Efforts to construct and express new material identities can similarly be observed in the production of pottery. Paul Blinkhorn $(2013,167-69)$ has noted that the pottery types being created at centres such as Stamford, Leicester, Thetford, and Northampton, while being of a generally similar design, display significant variety in their material components, mode of manufacture, and decoration. Although the development of certain Frankish-influenced wares, especially Stamford ware, has often been attributed to the Scandinavian settlers, Blinkhorn asserts an English impetus for this process, interpreting the diversity evident in the pottery types as a desire to assert disparate regional and even local 'urban' identities. The chronology for the production of these wares, however, is far from certain, and it is worth noting that the emergence of Frankish-style pottery production at Lincoln does appear to take place during the period of Scandinavian control (Ten Harkel 2013a, 183-84; see also Perry 2016). Regardless of whether incoming settlers played direct a role in driving the development of these new styles, the dramatic increase in the rate of pottery production during the late ninth and early tenth centuries means that the visibility of discrete regional and intraregional identities would have increased during the period of the Scandinavian occupation. 
The creation and importation of new material styles indicates that innovative material identities were being created, redefined, and expressed across the landscape. Kershaw $(2009,320)$ has argued that East Anglian disc brooches were worn with the express intention of signalling an affiliation with Scandinavian culture, and that in some contexts this might have provided the wearer with sociopolitical or economic benefits. Choices to exhibit a broadly AngloScandinavian or Continental cultural identity, or more tightly defined regional and intraregional affiliations, may have been made for similar reasons. These identities evolved in parallel with increased growth that led to the rejuvenation of urban sites and the creation of new independent centres whose relationships with groups living in the wider hinterland required negotiation (Ten Harkel 2013b, 169; Williams 2015, 30). Given the powerful role of material culture in establishing intragroup bonds (see Raffield and others 2016), the manipulation and strategic use of everyday objects was likely influential in the establishment and redefinition of identities among both urban and rural communities at a time when the political landscape was rapidly shifting.

The redefinition of identities and attempts by Scandinavian elites to assert political power can also be seen the development of coin economies. For much of the Viking Age, communities living in Scandinavia did not produce or use coinage. Trade was conducted instead through barter or the use of silver bullion, a practice that seems to have emerged in the ninth century at nodal marketplaces such as Hedeby, Kaupang, and Birka before becoming more widespread during the tenth century (Skre 2017). In England, however, Scandinavian elites were quick to experiment with coin production from an early date. Indeed, initial efforts to reproduce English coinage may have been undertaken by members of the Great Army even while it was campaigning in England during the 860s and 870s (Blackburn 2011, 225; Hadley and Richards 2016, 50).

From around the 880 s, coins produced in eastern Mercia at nodal centres such as Lincoln were imitations of English issues. Later issues would carry the names of Scandinavian rulers, but it is currently uncertain whether these are similarly imitations or genuine issues (see Williams 2011a, 69-71; Kershaw 2017, 175). The Lincoln Monogram coins produced during the 880s were one type of coin that closely imitated contemporaneous West Saxon issues, in this case Alfred of Wessex's London Monogram issue. While Lincoln would not rise in prominence as a mint until the 920s, it is apparent even at this early stage that elites were manipulating the London Monogram coins in order to express a distinct local identity. Instead of including the London monogram that featured on Alfred's coins, for example, the Lincoln issues featured a monogram bearing the city's name - LINCOLLA. Where the obverse of the London Monogram coins 
featured Alfred's name adjacent to the king's bust, the Lincoln issues instead bore the name of the moneyer who struck the coins. These efforts to adapt the London Monogram issues are interesting when considered in light of other evidence for the emergence of regional and local identities. In studying the Lincoln issues, Letty Ten Harkel $(2013 c, 9)$ has suggested that the individual overseeing the issue of the Lincoln Monogram coins omitted their name because they did not perceive themselves as being of 'royal' status. While it is important to acknowledge the possibility that the moneyer themselves may have been a member of the elite (Ten Harkel 2013c, 9-10), it is conceivable that certain conventions prevented lowerstatus members of the aristocracy from minting coinage, even in the absence of 'royal' power. This of course may be ascribing the elite with too much modesty, and there is tentative evidence to suggest that such individuals did occasionally mint coins. An unlocated mint named Sceldfor, argued by Cyril Hart (1995, 53) to have been situated at Great Shelford in Cambridgeshire, for example, is thought to have produced coins for an ambitious but otherwise unknown jarl named Sihtric during the tenth century. A further possibility however, and one that is worth thinking about when we consider the fragmented nature of the political landscape in eastern Mercia, is that the legend on the Lincoln Monogram coins reflects the emergence of a collective identity that focused not on individual rulers but instead on Lincoln itself (Ten Harkel 2018, 17). Was Lincoln, like other settlements noted in the Anglo-Saxon Chronicle, a nodal power base not for an individual jarl but rather for numerous independent armed groups that inhabited the surrounding landscape? It is impossible to say with any certainty, but this scenario would not be incompatible with other data suggesting that Lincoln was developing its own independent and distinctive identity during the early years of the Scandinavian occupation (Ten Harkel 2013b; 2013c; 2018). Similar evidence for expressions of collective identity through coin production can be seen in the St Edmund memorial coinage, which was produced in East Anglia from around 895. These coins feature a legend that commemorates the East Anglian king Edmund, who was killed during the Great Army's conquest of the region in 869. The similarities between this coinage and that circulating in the region prior to Edmund's death have been argued to reflect the resurgence of a distinctly East Anglian identity that may have been cultivated in direct opposition to the increasing power of Wessex (Williams 2014, 28), a hypothesis that is certainly plausible given West Saxon efforts to expand into southern Essex at this time.

Attempts by Scandinavian rulers to introduce and maintain coin economies can also potentially tell us much about the nature of political power and identity within the Scandinavian occupied territories. While the early coins minted in eastern Mercia tended to imitate contemporaneous English issues, Scandinavian 
rulers in York and East Anglia were quick to begin minting coins in their own names. In England, the establishment and maintenance of coin economies was closely associated with the identity and power of kings. While we should not arbitrarily assume that all Scandinavian elites would have sought to emulate this tradition, the minting of coins can be taken to indicate a degree of cultural assimilation and a desire by the rulers of York and East Anglia to express legitimate royal identities (Williams 2011a, 70; McLeod 2014, 228-30). In a recent study of coin economies in eastern and northern England, however, Jane Kershaw (2017, fig. 7) has argued that while coins seem to have been used in preference of bullion for economic transactions in urban areas, rural populations instead favoured a traditional Scandinavian-style bullion economy. Much can be made of this data, but for the purposes of this study the evidence for a regionally variable economy might imply two things. First, if we are to assume that the minting of coins reflects efforts to establish a centralized monetary economy, then the limited ability of the East Anglian and York kings to exclude the circulation of bullion, even within their own territories, might indicate a lack of consistent, formalized power outside of urban areas. Second, and in relation to this, the widespread use of a bullion economy in rural areas may indicate a discord between the interests of the elite and wider populations who sought to maintain localized networks of exchange (Kershaw 2017, 187). As noted by Gareth Williams (2011a, 70), the operation of a coin economy is a three-phase process. While a ruler must have sufficient power and access to resources to mint and distribute coinage, they must also be able not only to maintain this economy but to exclude other forms of currency from circulation. Unlike coinage, bullion could not be taxed, and as such the continued operation of a dual economy outside of urban areas may have served to deny rulers financial power (Kershaw 2017, 187).

The existence of a dual economy within the area of the Scandinavian settlements also impacts our understanding of how certain groups chose to express their identity. The use of bullion demanded the use of specialist equipment (scales, weights) and formulaic procedures to make even the smallest purchases. While coins can be exchanged rapidly, bullion transactions would have involved a more protracted process of measuring out and weighing payments, and likely would have been governed by various rules of etiquette. The use of silver bullion would have therefore represented an ostentatious marker of 'Scandinavian' identity, which in this case may have been layered with political overtones (Kershaw 2017, 187). The implications of this for the discussion of social and political cohesion across the Scandinavian occupied landscape are worth considering.

In light of the evidence discussed above, it seems that the late ninth and early tenth centuries were a time of innovation and change, with incoming 
Scandinavian elites, settlers, and regional populations all exercising myriad choices in their efforts to assert their presence, identity, and influence. While some groups sought to develop distinctly Scandinavian or more cosmopolitan material identities through the use of jewellery and ornamentation, there were also attempts to assert local or regional identities through the minting of coinage and pottery production. It is clear that many different types of material, ranging from the relatively mundane to those with high-status associations, were all imbued with layers of cultural significance and nuance. Each of these could be harnessed, deployed, or discarded as a means of emphasizing personal and communal affiliations, with the diversity of this material speaking to numerous processes of cultural negotiation taking place in both the urban and rural landscapes.

\section{The Rural Landscape of Settlement and Power}

As the above discussion has demonstrated, the short period of Scandinavian control in eastern and northern England was marked by numerous changes extending across the cultural, social, and political spheres, at both local and regional levels. While historical sources encourage scholars to focus on the processes taking place in major urban settlements, they also allude to a significant Scandinavian presence in the rural landscape. Although only a few sites of Scandinavian origin have been identified in rural areas to date, excavations and metal-detecting surveys have now begun to provide a number of tentative insights into processes of settlement and consolidation. At Goltho in Lincolnshire, a fortified manorial site enclosing a bow-sided hall and associated structures was established on the site of an existing settlement during the late Saxon period. The emergence of the manorial complex was accompanied by the appearance of Scandinavian- and Continental-style objects, and while the exact dating of the enclosure has been debated a late ninth- or early tenth-century date is possible (Beresford 1987; Richards 2004; Hadley 2006). If this is indeed the case (though cf. Reynolds 1999, 129-30), then the displacement of the existing settlement and the emergence of the manorial site may signal the presence of an intrusive elite group and a change in political management. While Guy Beresford (1987, 30) asserted that the manorial site was likely an English residence based on the morphology of the hall and a lack of evidence for destruction (a diagnostically 'viking' trait?) prior to the establishment of the site, there is no reason to assume that any transition in power, while socially and politically disruptive, would have incorporated violence. It is important to acknowledge that even a 'peaceful' period of political transition might have involved an element of coercion and the threat of violence, and in this the evidence should perhaps be considered within 
the context of the potential developments that may have been taking place in urban centres such as Stamford and Northampton, noted above.

Stronger evidence for a Scandinavian impetus for changes taking place in the rural landscape can now potentially be seen in Northumbria. Recent work by Dave Haldenby and Julian Richards $(2016,2018)$ at Cottam, East Riding of Yorkshire, has identified possible evidence for an intrusive Scandinavian presence at an Anglian settlement and periodic marketplace during the 860 s or 870 s. The range and concentration of the finds recovered at the site, which includes weights, parts of weighing scales, and pieces of silver bullion, has been taken to indicate that the site was briefly occupied by a contingent of the Great Army, either during its early incursions into Northumbria in 866-67 or as part of Halfdan's later campaigns and settlement during the mid-870s (Haldenby and Richards 2016; Richards and Haldenby 2018). The initial occupation was soon followed by a second phase of Scandinavian activity, which saw the establishment of a farmstead to the north of the Anglian settlement. The farmstead was associated with a number of AngloScandinavian-style finds, including three 'Norse bells', a Jelling-style copperalloy disc brooch, and lead disc-brooches similar to those found at Coppergate (Haldenby and Richards 2016). The layout of the farmstead speaks to the nature of a 'colonial'-style residence in that it was fronted by a massive ditch and internal bank, possibly topped with a palisade, and a large gateway structure (Richards 2001; 2004, 68-69). While Richards $(2004,69)$ originally cited a lack of evidence for violence at the site as indicating a continued English occupation (perhaps by farmers who wished to emulate Scandinavian fashions), it seems more likely that the developments at Cottam represent the intrusive actions of an outside group that were seeking to establish themselves in the local landscape. As the site was occupied only for a couple of generations at most, it is possible that subsequent political developments precipitated its relatively rapid abandonment (Richards 2001; Haldenby and Richards 2016).

The findings from Cottam now correspond with research suggesting that the impacts of the Great Army and the initial Scandinavian settlements might have been more widespread and disruptive than previously believed. In a study of metal-detecting finds from eastern England, Dawn Hadley and Julian Richards (2018), claim to have identified some thirty sites that were occupied by the Great Army while it was operating in England. These sites, like Cottam, have yielded a material signature (which includes lead gaming pieces, lead and copper-alloy weights, hacksilver and gold, pierced or cut Anglo-Saxon coins, and pierced or cut Anglo-Saxon and Irish dress accessories) that is broadly similar to those encountered at confirmed overwintering sites such as Torksey and Aldwark (Hadley and Richards 2018,3). While this material is perhaps less 'diagnostic' 
than Hadley and Richards maintain, it is possible that at least some of these finds reflect the presence of the Great Army, and indeed it would not be surprising to learn that elements of this force were traversing large swathes of the landscape as they sought out forage or plunder (see McLeod 2006, 145; Raffield 2016, 321).

Given the fluidity of the political situation in eastern and northern England during the late ninth and early tenth centuries, disruption to the settled landscape might have continued into the period of the Scandinavian occupation. Richards and Haldenby $(2018,344-45)$ have now identified a number of sites in southern Northumbria, known only through metal detecting, which appear to have been abandoned at this time. Further evidence for disruption can be seen in a decline in the power of the Church and the change in status of some ecclesiastical sites, as seems to have been the case at Flixborough in Lincolnshire (Abrams 2001a; 2001b; Hadley 2006; Ten Harkel 2011). The widespread nucleation of settlements at sites such as Wharram Percy, East Riding of Yorkshire (see Richards 2000; Wrathmell 2012), has also been attributed to the Scandinavian presence. It is important to emphasize, however, that further research is necessary to confidently associate these developments with the settlement process. Evidence for fluctuation in settlement patterns throughout the latter half of the first millennium, and the accommodation that at least some Scandinavian elites found with the Church, implies that many other factors may have contributed to these changes (see Hall 2000, 156; Hadley 2006, 28-54; Hamerow 2012, 67-70). Despite this, it is not unreasonable to assert that, following a disruptive (and perhaps violent) period of initial settlement, members of the Great Army and subsequent Scandinavian colonists would have reached an accord with local populations, precipitating the general trend towards acculturation and creolization that can be seen in the archaeological record moving into the tenth century (Hadley 2006; McLeod 2014).

\section{Discussion and Conclusions}

When taken together, the available historical and archaeological evidence reveals a complex picture of settlement and territorial consolidation in eastern and northern England following the turbulent years of 865-78. The initial settlements of the Great Army, followed by those of subsequent waves of colonists over years or perhaps decades, would have provided a context for radical changes within the settled landscape, driving both immigrant and regional populations to renegotiate their political and cultural affiliations.

It is important to recognize from the outset, however, that the extent of any changes and disruption resulting from the settlements must depend, at least to some extent, on the number of settlers themselves. If Jane Kershaw and Ellen 
Røyrvik's (2017) recent argument for a large number of Scandinavian colonists stands, then the impacts of this process could have been very great indeed. The number of settlers proposed by their study - some 20,000-35,000 people is comparable to that estimated for the Scandinavian colonization of Iceland, but unlike those in Iceland the groups establishing landholdings in England were colonizing an ancient, well-ordered, and hierarchical settled landscape. While this would have undoubtedly created friction and tensions between both immigrant groups and local populations, these encounters also provided opportunities for cultural contact and interaction, facilitating the exchange of knowledge, materials, traditions, and beliefs.

Despite the potential size of the immigrant population, it seems apparent that the initial settlers and their descendants did not universally seek to project or assert a strong Scandinavian cultural identity. While it may have been politically or socially advantageous to align with incoming Scandinavian colonists and elites, at least in certain situations, there is now good evidence to indicate that a range of culturally inspired material was also being used to exhibit cosmopolitan identities, or to signify affiliation with regional and local populations. The evident variety of the materials discussed in this article speaks not to a single process of social change but rather an infinite number of choices, personal experiments, and attempts by communities to better understand their place in a rapidly changing world.

While it is difficult to identify the key motors that underpinned these developments, it seems clear that the urban focus of the Scandinavian occupation provided a context for cultural interaction and transmission. Although the concept of urban living would have been unknown to the vast majority of the population in Scandinavia at this time, the years spent living within the confines of overwintering camps would have prepared the constituent elements of the Great Army for the initial occupation and development of regional settlements from the late 870s. As the winter camps were also centres for craft production and trade, it is similarly possible that the nucleation of these processes within overwintering sites paved the way for the development of large-scale production within the major urban centres of eastern and northern England (see Williams 2013, 18-19; Hadley and Richards 2016, 45-50; Raffield 2016, 319-24).

Although the Great Army had dispersed into the landscape by the end of the 870 s, it is important to consider how the structure and composition of this group might have continued to influence the emergence of regional and local identities in the years following the settlements. The demographic diversity and multiethnic composition of large viking raiding fleets has been well argued (McLeod 2014; Raffield 2016), and it is now clear that the Great Army should not be considered as a strictly 'military' force but rather as a mobile society or polity in 
its own right (Raffield 2016, 333). The constant exposure of kinship groups and warbands to new cultural influences and communities would have contributed to the shaping of unique 'in-group' identities that drew upon long histories of travel, warfare, and interaction with other groups (Raffield and others 2016). These identities were not static, but rather they could be signalled at different times and in different contexts through a range of means, including the use of dress and body ornamentation, language and dialect, and movement or actions (Raffield and others 2016). The continuing development and negotiation of these identities within the context of the settlements could have provided an impetus for the creation of new forms of material culture. The upheaval of the settlements, as well as the subsequent political fluidity of the landscape moving into the tenth century, would have also motivated local populations to experiment with and construct material identities that emphasized elements of both old and new sociopolitical and cultural affiliations.

The wider impacts of the Scandinavian settlement on the political and military landscape remain little understood. Certainly it seems that the balance of political power in Scandinavian occupied England was polyfocal, which likely reflects the initial dispersal of the Great Army into the former territories of Northumbria, Mercia, and East Anglia. This assumption has generally underpinned basic scholarly models for the formation of the 'Danelaw' since the nineteenth century. It is clear, however, that the make-up of the political landscape was far more complex than once believed. Even a cursory glance at the historical record reveals that there is little evidence to support the idea of substantive kingdoms or political blocs in eastern and northern England. Although there is some tentative archaeological and historical data to suggest that the East Anglian kings may have been able to initiate large construction projects and maintain their involvement in warfare until the region's capitulation in 917 , it is important to recognize that this evidence can be easily overstated. Questions concerning the power of the York kings also remain. While it has been suggested, for example, that York was able to extend its influence south of the Humber for short periods of time - an idea that does find some support in the minting of coins for the Hiberno-Norse king Sigtryggr (c. 921-27) at Lincoln (see Williams 2011b, 149; Gooch 2012, 80-89), additional archaeological evidence attesting to its hegemony is almost entirely lacking. Indeed, Gareth Williams (2011a, 45) has expressed doubt as to whether the territory of York can realistically be described as a 'kingdom' at all. Despite the efforts of some rulers to style themselves according to prevailing models of royal power, even those individuals who are described in historical sources as 'kings' may in fact have possessed little influence over wider regional landscapes and the groups that inhabited them (Raffield 2016, 326, 337). 
When examined in closer detail, the political landscape reveals itself as a complex tapestry of regional polities and perhaps even smaller autonomous landholdings. While historical evidence indicates that major urban centres were occupied by the more powerful members of the Scandinavian aristocracy, relationships between the groups inhabiting these settlements and their hinterlands remain unclear. It is possible that some elites may have parcelled out land to favoured subordinates (Ten Harkel 2013a, 185), thereby providing a potential context for the modification of existing settlements and the establishment of new sites such as those at Goltho and Cottam. This is a system that once again echoes the models of political allegiance and obligation that we see among viking warbands, raiding fleets, and armies (Williams 2013, 19; Price 2014, 57-58; Raffield 2016, 324-30), and as such it is possible that these arrangements continued to provide the basis for political and military organization in the years following the initial settlements (Raffield 2013,210-15). Later arrivals may also have owed nominal allegiance to those elites who resided in regional strongholds. Given the evident autonomy exercised by the 'holds' in their diplomatic dealings with the rulers of Wessex and Mercia, however, it seems clear that regional power structures were prone to fragmentation. The (failed?) attempts of certain rulers to introduce coin economies may similarly indicate a lack of formalized political control outside of urban areas, and again perhaps implies a level of autonomy on the part of various groups occupying the landscape.

In many ways, it is this very lack of internal social and political cohesion that represents the most striking feature of the Scandinavian occupation. It is perhaps not surprising to find that the political landscape of eastern and northern England seems to reflect the complex sociopolitical networks that dominated intergroup politics both in Scandinavia and among viking forces operating in western Europe (not least the Great Army itself) during the mid to late ninth century. On one hand, the ability of elites to negotiate numerous contracts and alliances with each other may have provided a measure of flexibility by allowing the rapid formation of raiding armies for offensive operations (Price 2014, 2016; Raffield 2013, 2016). When it came to matters of territorial defence, however, these fragile webs of political allegiance and obligation would have been vulnerable to West Saxon and Mercian exploitation. As the Chalgrave charter shows, a few pounds of gold or silver, offered at the right time, might have been enough to convince Scandinavian elites to part with their land, especially if they were subsequently allowed to maintain nominal control over their territories. This seems to have been the case with Jarl Thurferth who, as noted above, is recorded in the AngloSaxon Chronicle as submitting to Edward the Elder along with the army of Northampton in 917 (Hadley 2006, 60; Abrams 2001b, 138-39). Others are 
recorded as leaving England (presumably with a hefty bribe) in order to seek land or fortune elsewhere (see e.g. Anglo-Saxon Chronicles in Swanton 2000, 100; Abrams 2001b, 139). The willingness of English rulers to buy off their opponents may suggest that, where possible, diplomatic expediency rather than violence was the preferred method of achieving goals. For the Scandinavians, negotiation with an enemy who was not only willing to be lenient but also generous with gifts may have been preferable to relying on the help of unpredictable 'allies' who were themselves liable to capitulate in the face of aggression. Another influential factor may have been a simple realization of the futility of attempting to resist the combined strength of the West Saxon and Mercian field armies, especially in the wake of several disastrous Scandinavian military expeditions during the early tenth century.

But what does all of this mean for our understanding of the 'Danelaw' and the 'Five Boroughs'? It is necessary to stress again that the evidence discussed here can be interpreted in many ways, and that it can also be overstated given the ambiguity of the available data. However, in realistic terms, there is currently no archaeological evidence to suggest the existence of an autonomous or semiautonomous military confederation or political bloc in Mercia, despite the assertions of antiquarian scholars and the more implicit arguments of researchers today. The available archaeological and historical evidence certainly does not speak to the homogenizing models for the Scandinavian occupation that have so often been applied to the landscape. The evidence as it stands instead implies a concern with regional and local consolidation, perhaps even at an individual community or settlement level. The Scandinavian territories of eastern and northern England were in all likelihood fragmented, fractious polities, divided between groups that possessed no substantial political ties and for whom military cooperation was dependent wholly on the potential for individual gain. A lack of political cohesion and unity should therefore not be surprising, and it is not difficult to see how any pretext of defensive cooperation would have collapsed in the face of West Saxon and Mercian aggression.

How, then, should we define the political and cultural landscape of eastern and northern England during the ninth and tenth centuries? It seems clear that the continued application of the terms 'Danelaw' and 'Five Boroughs' as they are generally understood today serves to confuse the reality of the settlements, and there is a real risk of marginalizing evidence for the emergence of regional and local identities, economies, and power structures, which themselves demand further study. Is it necessary, however, to completely abandon these terms as anachronisms? It cannot be denied that, by the eleventh century, there was a broadly defined region within the English realm where the constituent 
population continued to adhere to Scandinavian legal practices and customs. When applied as a moniker for Scandinavian political and cultural influence at a regional level, therefore, the concept of the 'Danelaw' can be argued to retain at least some of its currency, even if the reality of the settled landscape during the ninth and tenth centuries was far more complex than later legal codes imply. If scholars should choose to continue using this term, then they might find it beneficial to redefine the concept of the 'Danelaw' from this more fundamental perspective. The question of the 'Five Boroughs' is altogether more difficult to address. Despite the tenth-century origins of this term, it is unclear whether it really does reflect the political or military landscape of eastern Mercia during the period of Scandinavian control. The long-standing model of a political or military confederation in eastern England is based almost entirely on the assertions of nineteenth- and early twentieth-century scholars (e.g. Worsaae 1852; Kendrick 1930; Shetelig 1940). It is impossible to reconcile these perspectives with the complex processes of social and cultural negotiation that were evidently taking place within numerous settlements and their associated regional landscapes, in addition to the general lack of evidence for political or military cohesion as seen in the historical record. Abandoning this term as an anachronism would therefore potentially facilitate the more fine-grained archaeological and historical studies that are necessary to understand the nature of the Scandinavian occupation. That said, it would be unwise to ignore subsequent references to the Five Boroughs and Seven Boroughs in the Anglo-Saxon Chronicle entries for 1013 and 1015 (AngloSaxon Chronicles in Swanton 2000, 143, 146), which despite their ambiguity do indicate that this concept meant something to the political commentators of the early eleventh century. As Gareth Williams $(2015,29)$ has noted, however, the very fact that the Chronicle mentions 'Seven Boroughs' at all may imply that the 'Five Boroughs' were less influential than scholars generally suppose. Suffice to say, given the uncertainties concerning the realities of the Five Boroughs, their political, military, or administrative functions, and the explicitly West Saxon perspective from which this concept derives, scholars should exercise increased caution when applying this term to the areas under Scandinavian control during the ninth and tenth centuries.

In acknowledging the politically fragmented nature of the landscape, a number of avenues for future research present themselves. Perhaps the most challenging task is to untangle the evidence for the Scandinavian settlements from that dating to the later tenth century. This will not be easy, but the development of more detailed chronologies is necessary if we are to fully understand processes of change as they were taking place at local and regional levels. There is also a clear need to better understand the political, economic, and cultural relationships 
between urban and rural populations. Further investigation into the impacts of the Great Army and the formative role that it likely played in establishing the blueprint for the settled landscape would greatly assist in this.

It is similarly necessary to move beyond the relatively restrictive descriptions provided by the Anglo-Saxon Chronicle, and to study political relationships and conflict at both inter- and intraregional levels. While the historical record inevitably focuses on conflict between English rulers and Scandinavian elites, the archaeological record offers the potential to explore the possibility of political tensions within the Scandinavian occupied landscape. Given the composite nature of the Great Army and the inevitably varied political affiliations of later waves of colonists, it cannot be assumed that the area of the settlements was not riven by the same factional conflicts that periodically erupted between Scandinavian groups living and operating elsewhere (for example in Ireland). It would be particularly useful, in this light, to examine the relationships between the so-called kingdom of York and regional elites inhabiting the lands south of the Humber, as well as the possibility of factional infighting within York itself, for example during the early 920s (Anglo-Saxon Chronicles in Swanton 2000, 105).

There is also a need to explore the potential for tension and conflict between various regional populations. While the heavily politicized narrative offered by the Anglo-Saxon Chronicle portrays the military campaigns of Æthelflæd and Edward the Elder as a liberation of eastern and northern England from its Scandinavian oppressors, these conquests in fact served to bring the former kingdoms of East Anglia, Northumbria, and Mercia into a consolidated English state for the very first time. In the centuries preceding the Viking Age, the balance of political power in England had shifted frequently between regional kingdoms as a result of warfare and diplomacy. Periods of peace were interspersed with conflict, which saw various kingdoms lose their influence only to experience a resurgence at a later date. The actions of the Great Army, however, brought large portions of Northumbria, Mercia, and East Anglia under Scandinavian control, thereby arguably providing a justification for the later conquest of these areas during the tenth century. It is worth considering how local populations would have reacted to these changes. Might some groups have actively joined the various 'Scandinavian' armies that are recorded as conducting raids into Wessex and western Mercia during the ninth and tenth centuries (see Sawyer 1958, 16-17; Baker and Brookes 2013, 21-22)? Could long-standing interregional tensions, furthermore, partially explain the need for Edward the Elder and Æthelflæd to instigate extensive programmes of fortification construction in their newly acquired territories? There are no simple answers to these questions at this time, but it is perhaps no coincidence that hybrid material identities continued to 
be expressed in the eastern and northern parts of the country following their incorporation into the English kingdom, perhaps as a form of passive resistance to southern rule (see Hadley 2006, 128-30; Kershaw 2009, 304-05). Scholars working in specialist fields (e.g. numismatics, pottery, stone sculpture, and small finds analysis) would have much to offer to this debate given the increasing potential for targeted studies of material culture to shed light on intraregional sociopolitical structures, economies, and ideologies.

To conclude, the aim of this article was to examine the historical and archaeological evidence for the Scandinavian settlement of eastern and northern England, and to consider whether this conforms or conflicts with traditional interpretative frameworks for the discussion of the Danelaw and Five Boroughs. The arguments presented here can only be considered as preliminary, but it seems clear that there is a need to set aside the broad, generalizing models for the Scandinavian occupation that have their roots in the cultural historical and antiquarian scholarship of the nineteenth and early twentieth centuries. Whether the terminology of the 'Danelaw' and 'Five Boroughs' would survive this process of course remains to be seen, but if this can be achieved then there is significant potential to develop a more complete understanding of the Scandinavian occupied landscape during the ninth and tenth centuries, and through this to shed further light on this formative period of English history.

\section{Acknowledgements}

I am grateful to Neil Price and Gordon Noble for supervising the $\mathrm{PhD}$ research that formed the basis of this article, and to Sarah Semple and Stefan Brink for their comments during my $\mathrm{PhD}$ examination. Thanks also go to Gareth Williams for reading and discussing early versions of the manuscript, and to David Roffe for kindly sharing Christine Mahany's unpublished manuscript on Stamford. I would finally like to thank two anonymous reviewers and the editor, Pernille Hermann, whose comments and guidance have greatly improved the final text, particularly in relation to the discussion concerning the legal definition of the 'Danelaw'. The writing of this article was funded by a grant awarded to The Viking Phenomenon project by the Swedish Research Council (2015-00466). 


\section{Works Cited}

\section{Primary Sources}

Attenborough, Frederik Levi, ed. and trans. 1922. The Laws of the Earliest English Kings, Cambridge: Cambridge University Press

Bately, Janet M., ed. 1986. The Anglo-Saxon Chronicle: A Collaborative Edition, III: MS A., Cambridge: Brewer

Campbell, Allen, ed. 1962. The Chronicle of Ethelweard, London: T. Nelson

Downer, Leslie John, ed. 1972. Leges Henrici Primi, Oxford: Clarendon

Electronic Sawyer. 2019. S396. < http://www.esawyer.org.uk/charter/396.html> [accessed 2 February 2019]

Garmonsway, George Norman, trans. 1972. The Anglo-Saxon Chronicle. London: Dent

Irvine, Susan, ed. 2004. The Anglo-Saxon Chronicle: A Collaborative Edition, vir: MS E, Cambridge: Brewer

O’Brien O'Keeffe, Katherine, ed. 2001. The Anglo-Saxon Chronicle: A Collaborative Edition, v: $M S C$, Cambridge: Brewer

Robertson, Agnes Jane, ed. and trans. 1925. The Laws of the Kings of England from Edmund to Henry I, Cambridge: Cambridge University Press

Swanton, Michael, trans. 2000. The Anglo-Saxon Chronicles, London: Phoenix

Whitelock, Dorothy, ed. 1979. English Historical Documents, I: c. 500-1042, 2nd edn, Oxford: Oxford University Press

\section{Secondary Sources}

Abrams, Lesley. 2001a. 'The Conversion of the Danelaw', in Vikings and the Danelaw: Select Papers from the Proceedings of the Thirteenth Viking Congress, ed. James GrahamCampbell and others, Oxford: Oxbow, 31-44

Abrams, Lesley. 2001b. 'Edward the Elder's Danelaw', in Edward the Elder, 899-924, ed. Nick J. Higham and David H. Hill, London: Routledge, 128-43

Ayers, Brian. 2011. 'The Growth of an Urban Landscape: Recent Research in Early Medieval Norwich', Early Medieval Europe 19, 175-204

Baker, John, and Stuart Brookes. 2013. Beyond the Burghal Hidage: Anglo-Saxon Civil Defence in the Viking Age, Leiden: Brill

Beresford, Guy. 1987. Goltho: The Development of an Early Medieval Manor, c. 850-1150, London: Historic Buildings and Monuments Commission for England

Biddle, Martin, and Birthe Kjølbye-Biddle. 1992 'Repton and the Vikings', Antiquity 66, $36-51$

Biddle, Martin, and Birthe Kjølbye-Biddle. 2001. 'Repton and the "Great Heathen Army", 873-4', in Vikings and the Danelaw: Selected Papers from the Proceedings of the Thirteenth Viking Congress, ed. James Graham-Campbell and others, Oxford: Oxbow, 45-96 
Blackburn, Mark. 2011. 'The Viking Winter Camp at Torksey, 872-3', in Mark Blackburn, Viking Coinage and Currency in the British Isles, 371-900, London: British Numismatic Society, 221-64

Blair, John. 1996. 'Palaces or Minsters? Northampton and Cheddar Reconsidered', AngloSaxon England 25, 97-121

Blinkhorn, Paul. 2013. 'No Pots Please, We're Vikings: Pottery in the Southern Danelaw, 850-1000', in Everyday Life in Viking-Age Towns, ed. Dawn Hadley and Letty Ten Harkel, Oxford: Oxbow, 193-208

Boyle, Michael. 2009. An Archaeological Excavation at Jubilee Close, Thetford, Norfolk, Unpublished Excavation Report

Cameron, Kenneth. 1965. Scandinavian Settlement in the Territory of the Five Boroughs: The Place-Name Evidence, Nottingham: The English Place-Name Society

Chapman, Andy. 1998. 'Excavation of the Town Defences at Green Street, Northampton 1995-6', Northamptonshire Archaeology 28, 25-60

Clinton, Mark. 2014. 'The Viking Longphort of Linn Duachaill: A First Report', Peritia 24-25, 123-40

Crowson, Andy. 1999. Evaluation Excavation of Thetford Town Library Car Park, Unpublished Excavation Report

Davison, Andrew, and D. H. Evans. 1985. 'Excavations on Botolph Street and St George's Street', in Excavations in Norwich, 1971-1978, II, ed. Malcom Atkin, Alan Carter, and D. H. Evans, East Anglian Archaeology 26, Norwich: University of East Anglia, 87-143

Dumville, David N. 1992. 'The Treaty of Alfred and Guthrum', in David N. Dumville, Wessex and England from Alfred to Edgar: Six Essays on Political, Cultural and Ecclesiastical Revival, Woodbridge: Boydell, 1-14

Dunmore, Stephen, Tim Loader, and Keith Wade. 1976. 'Ipswich Archaeological Survey: Second Interim Report', East Anglian Archaeology 3, 135-40

Edgeworth, Matthew. 2004. 'Recent Archaeological Investigations in Bedford Town Centre: Evidence for an Early Northern Boundary?', Bedfordshire Archaeology 25, 190-200

Edgeworth, Matthew. 2007. '“Anglo-Saxon” and Medieval Bedfordshire - AD400-1550', in Martin Oake and others, Bedfordshire Archaeology: Research and Archaeology: Resource Assessment, Research Agenda and Strategy, Exeter: Short Run Press, 87-98

Foard, Glenn. 1995. 'The Early Topography of Northampton and its Suburbs', Northamptonshire Archaeology 26, 109-22

Gooch, Megan. 2012. 'Money and Power in the Viking Kingdom of York, c. 895-954' (unpublished doctoral thesis, University of Durham)

Graham-Campbell, James, and others, eds. 2001. Vikings and the Danelaw: Selected Papers from the Proceedings of the Thirteenth Viking Congress, Oxford: Oxbow

Hadley, Dawn M. 2000. The Northern Danelaw: Its Social Structure, c. 800-1100, London: Leicester University Press

Hadley, Dawn M. 2001. 'In Search of the Vikings: The Problems and the Possibilities of Interdisciplinary Approaches', in Vikings and the Danelaw: Select Papers from the Proceedings of the Thirteenth Viking Congress, ed. James Graham-Campbell and others, Oxford: Oxbow, 13-30 
Hadley, Dawn M. 2002. 'Viking and Native: Rethinking Identity in the Danelaw', Early Medieval Europe 11, 45-70

Hadley, Dawn M. 2006. The Vikings in England: Settlement, Society and Culture, Manchester: Manchester University Press

Hadley, Dawn M., and Julian D. Richards, eds. 2000. Cultures in Contact: Scandinavian Settlement in England in the Ninth and Tenth Centuries, Turnhout: Brepols

Hadley, Dawn M., and Julian D. Richards. 2016. 'The Winter Camp of the Viking Great Army, AD 872-73, Torksey, Lincolnshire', The Antiquaries Journal 96, 23-67

Hadley, Dawn M., and Julian D. Richards. 2018. 'In Search of the Viking Great Army: Beyond the Winter Camps', Medieval Settlement Research 33, 1-17

Haldenby, Dave, and Julian D. Richards. 2016. 'The Viking Great Army and its Legacy: Plotting Settlement Shift Using Metal-Detected Finds', Internet Archaeology 42 <https://dx.doi.org/10.11141/ia.42.3>

Hall, Richard A. 1989. 'The Five Boroughs of the Danelaw: A Review of Present Knowledge', Anglo-Saxon England 18, 146-206

Hall, Richard A. 2000. 'Scandinavian Settlement in England - The Archaeological Evidence', Acta archaeologica 71, 147-57

Hamerow, Helena. 2012. Rural Settlements and Society in Anglo-Saxon England, Oxford: Oxford University Press

Harrison, Stephen. 2015. "Warrior Graves"? The Weapon Burial Rite in Viking Age Britain and Ireland', in Maritime Societies of the Viking and Medieval World, ed. James H. Barrett and Sarah Jane Gibbon, London: Maney, 299-319

Hart, Cyril. 1992. The Danelaw, London: Bloomsbury

Hart, Cyril R. 1995. 'The Aldewerke and Minster at Shelford, Cambridgeshire', AngloSaxon Studies in Archaeology and History 8, 42-68

Haslam, Jeremy. 1987. 'Market and Fortress in England in the Reign of Offa', World Archaeology 19, 73-96

Haslam, Jeremy. 2010. 'The Development of London by King Alfred: A Reassessment', Transactions of the London and Middlesex Archaeological Society 61, 109-44

Haslam, Jeremy. 2011. 'King Alfred, Mercia and London in 874-886: A Reassessment', Anglo-Saxon Studies in Archaeology and History 17, 120-46

Haslam, Jeremy. 2017. 'The Territorial and Strategic Context of Stamford, Lincolnshire, in the Early Tenth Century', Journal of Historical Geography 58, 23-38

Higham, Nicholas J., and David H. Hill, eds. 2001. Edward the Elder, 899-924, London: Routledge

Hill, David. 1981. An Atlas of Anglo-Saxon England, Oxford: Basil Blackwell

Historic England. 2019. 'The EH Monument Type Thesaurus' <http://thesaurus. historicengland.org.uk/thesaurus.asp?thes_no=1> [accessed 2 February 2019]

Holman, Katherine. 2001. 'Defining the Danelaw', in Vikings and the Danelaw: Select Papers from the Proceedings of the Thirteenth Viking Congress, ed. James GrahamCampbell and others, Oxford: Oxbow, 1-12

Innes, Matthew. 2000. 'Danelaw Identities: Ethnicity, Regionalism and Political Allegiance', Cultures in Contact: Scandinavian Settlement in England in the Ninth and Tenth Centuries, ed. Dawn M. Hadley and Julian D. Richards, Turnhout: Brepols, 65-88 
Jarvis, Michael. 1996. Central Library, Lincoln: Archaeological Excavation and Assessment, I, Unpublished Excavation Report

Jesch, Judith. 2015. The Viking Diaspora, London: Routledge

Kendrick, Thomas D. 1930. A History of the Vikings, London: Methuen

Kershaw, Jane. 2009. 'Culture and Gender in the Danelaw: Scandinavian and AngloScandinavian Brooches', Viking and Medieval Scandinavia 5, 295-325

Kershaw, Jane. 2013. Viking Identities: Scandinavian Jewellery in England, Oxford: Oxford University Press

Kershaw, Jane. 2017. 'An Early Medieval Dual-Currency Economy: Bullion and Coin in the Danelaw', Antiquity 91.355, 173-90

Kershaw, Jane, and Ellen C. Røyrvik. 2016. 'The "People of the British Isles" Project and Viking Settlement in England', Antiquity 90.354, 1670-80

Kershaw, Paul. 2000. 'The Alfred-Guthrum Treaty', in Cultures in Contact: Scandinavian Settlement in England in the Ninth and Tenth Centuries, ed. Dawn M. Hadley and Julian D. Richards, Turnhout: Brepols, 43-64

Knight, David, and Scott Lomax. 2015. The Origins of Nottingham: Archaeological Excavations in the Medieval Town from 1969 to 1980, Unpublished Report <https:// doi.org/10.5284/1029430>

Lambert, Tom. 2018. 'Frontier Law in Anglo-Saxon England', in Crossing Borders: Boundaries and Margins in Medieval and Early Modern Britain, ed. Sarah M. Butler and Krista J. Kesselring, Leiden: Brill, 21-42

Leslie, Stephen, and others. 2015. 'The Fine-Scale Genetic Structure of the British Population', Nature 519, 309-14

Loyn, Henry R. 1962. Anglo-Saxon England and the Norman Conquest, London: Longman

Mahany, Christine M. 1978. Stamford: Castle and Town, South Lincolnshire Archaeology 2, Stamford: South Lincolnshire Archaeology Unit

Mahany, Christine M., ed. Forthcoming. Excavations at Stamford Castle, 1971-76, Unpublished Excavation Report

Mahany, Christine, Alan Burchard, and Gavin Simpson. 1982. Excavations in Stamford Lincolnshire, 1963-1969, London: Society for Medieval Archaeology

Mahany Christine M., and David Roffe. 1983. 'Stamford: The Development of an AngloScandinavian Borough', Anglo-Norman Studies 5, 197-219

McLeod, Shane. 2006. 'Feeding the Micel Here in England, c. 865-878', Journal of the Australian Early Medieval Association 2, 141-56

McLeod, Shane. 2013. 'The Acculturation of Scandinavians in England: A Consideration of the Burial Record,'Journal of the Australian Early Medieval Association 9, 61-88

McLeod, Shane. 2014. The Beginning of Scandinavian Settlement in England, Turnhout: Brepols

Percival, John, and Suzie Westall. 2008. NAU Archaeology Report No. 1583A: An Archaeological Evaluation at Anglia Square, Norwich; Phase 1, Unpublished Excavation Report

Perring, Dom. 1981. Early Medieval Occupation at Flaxengate, Lincoln, London: Council for British Archaeology for the Lincoln Archaeological Trust 
Perry, Gareth J. 2016. 'Pottery Production in Anglo-Scandinavian Torksey (Lincolnshire): Reconstructing and Contextualising the Chaîne Opératoire', Medieval Archaeology 60, 72-114

Price, Neil. 2014. 'Ship Men and Slaughter Wolves. Pirate Polities in the Viking Age', in Persistent Piracy: Maritime Violence and State Formation in Global Historical Perspective, ed. Stefan Amirell and Leos Müller, New York: Palgrave, 51-68

Price, Neil. 2016. 'Pirates of the North Sea? The Viking Ship as Political Space', in Moving on: Interdisciplinary Perspectives on Past Colonization, Maritime Interaction and Cultural Integration, ed. Håkon Glørstad, Zanette Tsigaridas Glørstad, and Lene Melheim, Sheffield: Equinox, 149-76

Raffield, Ben. 2013. 'Landscapes of Conflict and Control: Creating an Archaeological Atlas of Scandinavian Occupied England, AD 878-954' (unpublished doctoral thesis, University of Aberdeen)

Raffield, Ben. 2016. 'Bands of Brothers: A Re-appraisal of the Viking Great Army and its Implications for the Scandinavian Colonization of England', Early Medieval Europe 24, 308-37

Raffield, Ben. 2019. 'The Slave Markets of the Viking World: Comparative Perspectives on an "Invisible Archaeology", Slavery \& Abolition 40, 682-705

Raffield, Ben, and others. 2016. 'Ingroup Identification, Identity Fusion, and the Formation of Viking Warbands', World Archaeology 48, 35-50

Reynolds, Andrew. 1999. Later Anglo-Saxon England: Life and Landscape, Stroud: Tempus

Richards, Julian D. 2000. 'The Anglo-Saxon and Anglo-Scandinavian Evidence', in Wharram: A Study of Settlement on the Yorkshire Wolds, vin: The South Manor Area, ed. Paul A. Stamper and R. A. Croft, York: York University Archaeological Publications, 195-200

Richards, Julian D. 2001. 'Anglian and Anglo-Scandinavian Cottam: Linking Digital Publication and Archive, Internet Archaeology $10<$ https://intarch.ac.uk/journal/ issue 10/richards_index.html> [accessed 1 August 2020]

Richards, Julian D. 2004. Viking-Age England, Stroud: Tempus

Richards, Julian D., and Dave Haldenby. 2018. 'The Scale and Impact of Viking Settlement in Northumbria', Medieval Archaeology 62, 322-50

Rogerson, Andrew, and Carolyn Dallas. 1984. Excavations in Thetford 1948-59 and 1973-8, East Anglian Archaeology 22, Norwich: University of East Anglia

Russell, Ian, and Maurice F. Hurley, eds. 2014. Woodstown: A Viking-Age Settlement in Co. Waterford, Dublin: Four Courts

Sawyer, Peter H. 1958. 'The Density of the Danish Settlement in England', University of Birmingham Historical Journal 6, 1-17

Sawyer, Peter H. 2001. The Oxford Illustrated History of the Vikings, Oxford: Oxford University Press

Shetelig, Haakon, ed. 1940. Viking Antiquities in Great Britain \& Ireland, I, Oslo: Aschehoug

Skre, Dagfinn. 2017. 'Monetary Practices in Early Medieval Western Scandinavia (5th-10th Centuries AD)', Medieval Archaeology 61, 277-99 
Sparey-Green, Christopher. 2002. 'Excavations on the South-Eastern Defences and Extramural Settlement of Little Chester, Derby 1971-2: Discussion', Derbyshire Archaeological Journal 122, 122-46

Ten Harkel, Letty. 2011. 'Land or Gold? Changing Perceptions of Landscape in Viking Age Lincolnshire', Assemblage 11, 15-33

Ten Harkel, Letty. 2013a. 'Of Towns and Trinkets: Metalworking and Dress-Accessories in Viking-Age Lincoln', in Everyday Life in Viking-Age Towns, ed. Dawn M. Hadley and Letty Ten Harkel, Oxford: Oxbow, 172-92

Ten Harkel, Letty. 2013b. 'Urban Identity and Material Culture: A Case Study of VikingAge Lincoln, c. AD 850-1000', Anglo-Saxon Studies in Archaeology and History 18, 157-73

Ten Harkel, Letty. 2013c 'The Urbanization of Viking Age Lincoln: A Numismatic Perspective', The Medieval Journal 3, 1-48

Ten Harkel, Letty. 2018. 'Ethnic Identity or Something Else? The Production and Use of Non-Ferrous Dress-Accessories and Related Items from Early Medieval Lincoln', Anglo-Saxon Studies in Archaeology and History 21, 1-27

Ten Harkel, Letty, Rosie Weetch, and Victoria Sainsbury. 2016. 'An Early Medieval Polychrome-Enamelled Brooch from Flaxengate, Lincoln: Continental Fashions in an Anglo-Scandinavian Town', Medieval Archaeology 60, 57-71

Wade, Keith. 1993. 'The Urbanisation of East Anglia: The Ipswich Perspective', in Flatlands and Wetlands: Current Themes in East Anglian Archaeology, ed. Julie Gardiner, East Anglian Archaeology 50, Norwich: The Scole Archaeological Committee for East Anglia, 144-51

Wade, Keith. 2014. IAS 4801: Site Summary <https://doi.org/10.5284/1034354>

Wallis, Heather. 2010. Anglia Square, Norwich: Phase 2 Archaeological Evaluation, Unpublished Excavation Report

Webster, Leslie E., and John Cherry. 1972. 'Medieval Britain in 1971', Medieval Archaeology 16, 147-212

Webster, Leslie E., and John Cherry. 1973. 'Medieval Britain in 1972', Medieval Archaeology 17, 138-88

West, Stanley E. 1963. 'Excavations at Cox Lane (1958) and the Town Defences, Shire Hall Yard, Ipswich (1959)', Proceedings of the Suffolk Institute of Archaeology 29.3, 233-303

Williams, John H. 1984. 'From "Palace" to "Town": Northampton and Urban Origins', Anglo-Saxon England 13, 113-36

Williams, Gareth. 2011a. 'The Cuerdale Coins', in The Cuerdale Hoard and Related Viking-Age Silver and Gold from Britain and Ireland in the British Museum, ed. James Graham-Campbell, London: The British Museum Press, 39-72

Williams, Gareth. 2011b. 'Coinage and Monetary Circulation in the Northern Danelaw in the 920s in the Light of the Vale of York Hoard', in Studies in Early Medieval Coinage, II, ed. Tony Abramson, Woodbridge: Boydell, 156-65

Williams, Gareth. 2013. 'Towns and Identities in Viking England', in Everyday Life in Viking-Age Towns, ed. Dawn M. Hadley and Letty Ten Harkel, Oxford: Oxbow, 14-34 
Williams, Gareth. 2014. 'Coins and Currency in Viking England, AD 865-954', Early Medieval Monetary History: Studies in Memory of Mark Blackburn, ed. Rory Naismith, Martin Allen, and Elina Screen, Farnham: Ashgate, 13-38

Williams, Gareth. 2015. 'Viking Camps and the Means of Exchange in Britain and Ireland in the Ninth Century', in The Vikings in Ireland and Beyond: Before and after the Battle of Clontarf, ed. Howard B. Clarke and Ruth Johnson, Dublin: Four Courts, 93-116

Worsaae, Jens J. A. 1852. An Account of the Danes and Norwegians in England, Scotland, and Ireland, London: John Murray

Wrathmell, Stuart. 2012. 'Dating the Foundation of the Medieval Village', in Wharram: A Study of Settlement on the Yorkshire Wolds, XIII: A History of Wharram Percy and its Neighbours, ed. Stuart Wrathmell, York: York University Archaeological Publications, 203-06

Youngs, Susan M., John Clark, and Terry Barry. 1984. 'Medieval Britain and Ireland in 1983', Medieval Archaeology 28, 203-65 